\title{
International Journal of Development Education and Global Learning
}

Article

\section{Ecological global citizenship education: a reframing}

\section{Alyson Jenkins}

Adult Education, Yorkville University, Canada; Alysonjenkins7@gmail.com

Submission date: 24 February 2021; Acceptance date: 8 September 2021; Publication date: 14 December 2021

\section{How to cite}

Jenkins, A. (2021) 'Ecological global citizenship education: a reframing'. International Journal

of Development Education and Global Learning, 13 (2), 94-108. DOI: https://doi.org/10.14324/

IJDEGL.13.2.03.

\section{Peer review}

This article has been peer-reviewed through the journal's standard double-blind peer review, where both the reviewers and authors are anonymised during review.

\section{Copyright}

2021, Alyson Jenkins. This is an open-access article distributed under the terms of the Creative Commons Attribution Licence (CC BY) 4.0 https://creativecommons.org/licenses/by/4.0/, which permits unrestricted use, distribution and reproduction in any medium, provided the original author and source are credited • DOI: https://doi.org/10.14324/IJDEGL.13.2.03.

\section{Open access}

International Journal of Development Education and Global Learning is a peer-reviewed open-access journal.

\begin{abstract}
A reconceptualization of education for sustainability and global citizenship education (GCE) is proposed, considering evidence from the United Nations decade of education for sustainable development (ESD) and from research with policymakers and adult educators in Wales. In this reframing, global citizenship education is foregrounded, and the model is underpinned by an ecological ethos, where webs of interconnections are highlighted. The model is informed by critical and holistic adult education, and it includes a focus on relational learning and on the affective domain, where emotions are recognised and valued alongside the rational and cognitive. These elements are supported by an ethic of care, which is introduced as a starting point for making what can appear as abstract concepts or remote issues, immediate and relevant to learners' lived experience. The synthesis of the various theoretical perspectives embodies an inclusive 'ecological global citizenship education', where educators and learners are supported to engage with difficult and emotive topics. Dialogue is proposed as the method at the centre of a pedagogy that is critical and humanistic, and that facilitates and supports the often-uncomfortable learning as we honestly and critically examine ourselves and our world within a learning community.
\end{abstract}

Keywords global citizenship; transformative adult education; ecological; care theory; emotions; dialogue 


\section{Introduction}

Human activity is having a significant and increasing impact on the planet. Steffen et al. (2011, 2015) have mapped global environmental, economic and social trends, and their research illustrates a great acceleration that includes loss of biodiversity and ecological degradation, coupled with increasing social polarization and inequalities. Current paradigms of 'progress' are proving unsustainable, and the intensity and speed of change is having a detrimental effect on planet and people (United Nations, 2019). Globally, there have been many education initiatives to address environmental sustainability; however, from the evaluations of the United Nations Decade for Education for Sustainable Development (200514), it was overwhelmingly business as usual (Huckle and Wals, 2015; UNESCO, 2010, 2013, 2014). Social, political and ethical issues were not being integrated or addressed to the same extent as environmental ones, and this article is a contribution to redressing this imbalance. It is fundamentally informed by adult learning theory and practice, and it proposes a perspective shift that foregrounds the affective learning domain within a critical pedagogy and includes care theory as an ethico-political starting point. The model or framework is grounded in an ecological ethos, and the synthesis of this with the other elements distinguishes it from, but also contributes to, discourses on environmental global citizenship education and ecopedagogy.

The term 'sustainability education' is used in place of education for sustainable development (ESD) because the contested concept of development has historically been linked with Western ideologies and notions of progress. Not describing it as an education for sustainability provides a less normative concept.

This reframing emerged from the findings of research conducted in Wales, UK (Jenkins, 2018), which examined the response to, and implementation of, the initiative 'Education for Sustainable Development and Global Citizenship' (ESDGC; Welsh Government, 2008) in the adult and community learning sector. Conceptual confusion among policymakers and practitioners emerged as one of the main barriers to successful implementation of the ESDGC strategy. Despite explicitly linking education for sustainable development with global citizenship education (GCE), tutors and curriculum/ programme developers found it easier to engage with environmental issues, and GCE was neglected. The same picture emerged in the schools sector in Wales, as teachers appeared to be reticent to broach what they perceived as problematic ethical and political issues (Bennell, 2011; Norcliffe and Bennell, 2010).

The term used to encapsulate a reconceptualised model is 'ecological global citizenship education'. Alongside adult learning, care theory is included in the rationale, as it can provide starting points for a more immediate form of learning, and a way to articulate the ethico-political core of this form of education. Recently, millions of people, particularly young people, have become vocal and active in drawing attention to climate change, demanding that those in power act on a moral imperative for life on earth. They care about the desecration of the biosphere. Therefore, it is apposite to consider care ethics and the practical discourses it can contribute.

\section{Background}

\section{Environmental sustainability education and global citizenship education}

Integrating social and economic discourses with environmental ones was part of the transition from environmental education to education for sustainable development, but this model has not achieved integration, or engaged the hearts and minds of educators and learners. In an article that examines key publications from the United Nations Decade of ESD, Huckle and Wals (2015) are critical of UNESCO's approach for failing to challenge the neoliberalism at the root of most unsustainable development. 
Often lacking or omitted in the literature on sustainable development is the discourse of community development, even though both have a critical social justice orientation. There are those who argue that sustainability can only be realised by reducing inequality and poverty in specific localities through appropriate policy creation and including the voices of disenfranchised and marginalised people, locally and globally (Agyeman, 2005; Warburton, 2013). Emphasising the importance of developing a critical cultural ecoliteracy that values indigenous and traditional knowledge, Bowers $(2001,2002,2017)$ and Burns (2015) highlight how value systems that recognise high- and low-status knowledge contribute to systemic racism, prejudice and environmental exploitation. This echoes the decolonial perspective of Andreotti (2010, 2011), Andreotti and Souza (2012) and Sund and Pashby (2020) in global citizenship education.

Turning to GCE, it is vital to understand the antecedents of global citizenship and how it is variously conceptualised, if educators are to meaningfully engage with, and integrate it with, environmental sustainability education (Ellis, 2015; Gaudelli, 2003, 2016; Schattle, 2008, 2012). The dominant model for citizenship is a liberal one based on civil, political and social rights; other recognised models include the civic republican and communitarian (Dobson, 2003, 2005; Heater, 2013), where an ethic of civic virtue prevails, and serving the common good is how people fulfil their potential as citizens. Critical global citizenship education informs and stimulates political participation and questions moral norms (Bourn, 2014); however, there are many pathways to, and expressions of, global citizenship. In their typology of global citizenship education, Oxley and Morris (2013) identify environmental global citizenship as a category which can be a unifying field that centres on ethics. It is this broad category that provides a starting point for a reframing of sustainability education and GCE.

\section{Bringing the discourses together}

Examples of how the discourses of environmental sustainability and global citizenship have recently been integrated include sustainable citizenship (Huckle, 2014) and environmental citizenship (Dobson, 2007; Misiaszek, 2017). Ecopedagogy is a neologism that encompasses many of these ideas and merges critical and environmental discourses. Misiaszek $(2015,2016,2017)$ places ecopedagogy at the centre of critical, dialectic approaches, and he concurs with many authors on the need for a paradigm shift in education, where ecological pedagogy is an essential part of global citizenship education and vice versa. A critical global citizenship education can be the starting point for recognising the network of mutuality of all life, and for developing an ecoliteracy that understands that ecological sustainability cannot be realised without personal and local starting points within a global frame of reference. Global citizenship education calls for an expansive exploration of new philosophies in line with a more compassionate humanity:

Nowadays, to say that we are clever animals is not to say something philosophical and pessimistic but something political and hopeful - namely, if we can work together, we can make ourselves into whatever we are clever and courageous enough to imagine ourselves becoming. This is to set aside Kant's question 'What is man?' and to substitute the question 'What sort of world can we prepare for our great grandchildren?' (Rorty, 1998: 175)

This quotation highlights the ethical question regarding our responsibility to future generations, and in its Well-Being of Future Generations Act, the Welsh Government (2015) requires public bodies in Wales to think about the long-term impact of their decisions, to work with people, communities and each other, and to address persistent problems such as poverty, health inequalities and climate change. In their review of ESD and ESDGC policy in the UK, Bamber et al. (2016) highlight the growing importance of global citizenship education in addressing these issues. It provides the inescapably political and ethical dimensions, and integrating environmental sustainability and global citizenship has never been more important as we face climate change and its impact. 


\section{Transformative adult learning: synergy}

Transformative learning is an important theory in adult education; it was first proposed by Mezirow (1981, 2000), and it involves critically reflecting on experience and engaging in dialogue to realise agency more fully through perspective transformation. Previously uncritically assimilated assumptions, beliefs, values and perspectives are questioned so that the mindset becomes more open and permeable, and we revise our world view and develop an increased awareness. This learning process includes the cognitive and affective domains - the affective is concerned with feelings, attitudes, values and motivations, and it is sometimes neglected despite being a vital element in human learning (Jarvis, 2006).

The important role that emotions play in our cognitive functioning, in our ability to learn, communicate and to solve problems, is being increasingly recognised. Emotions, like learning itself, are dynamic, social and context dependent (Immordino-Yang, 2015), and are part of reasoning, rationality, learning and meaning making; they are a way of knowing, and not, as has been previously thought, barriers to reason and knowledge (Merriam et al., 2012). There is a consensus that attending to emotions and feelings in contexts, interactions and relationships is vital in holistic adult education, and that the process of becoming critical thinkers is emotive as well as rational, as it explores alternative ways of thinking and acting (Brookfield, 2011).

Hoggan et al. (2017), in their discussion on perspective transformation in adult learning, highlight three core ideas. The first is intersubjectivity and relational learning, which addresses the false dichotomies between the individual and the social, the private and the public, and the cognitive and the emotional. Second, there is the importance of starting from where the learner is, and recognising the underlying premise of normativity in all forms of education. There is sometimes the assumption that some learner perspectives are wrong, or in need of adjusting, and we should question the assumptions of transformative learning which rest on a Eurocentric philosophy (Bowers, 2005). And third, this form of learning has an emancipatory praxis based on critical reflection and a self-directed approach which has a moral, social or political purpose. It includes democratic participation and an engagement with the complex and contested notions of human freedom and solidarity (Torres, 2013). These features distinguish it from education with an instrumental purpose.

For both teachers and learners, dealing with the issues in sustainability education and GCE can be uncomfortable, as we confront some of the worst aspects of humanity. However, a realistic engagement with the challenges, and even the traumas and tragedies, of this world is needed, rather than a denial (Huckle, 2012; Selby and Kagawa, 2011). Todd (2015) emphasises the need to face reality and not turn a blind eye, avoid, negate, dilute, ignore or, worse, deny. If we do this, we cannot give an adequate response to questions of violence, hate, suffering, poverty, war, racism, sexism and ecological degradation.

Transformative learning is transformative for the individual, and it holds the potential of being transformational for society and the world. It involves developing critical thinking, and it uses a critical pedagogy framework which explores the wider world, has a social and collective focus, is context driven and is explicitly political in its critique of ideology. In the classroom, the individual and the collective come together through a learner-centred, dialogic pedagogy (Brookfield, 2011; Johnson and Morris, 2010). This relational learning, and the role of dialogue and discussion as part of transformative learning, are highlighted by many authors (Lysaker and Furuness, 2011; Taylor and Snyder, 2012).

Despite a trend towards vocational courses, and away from humanistic and critical education, adult and community learning can contribute to strategies for transformation in an age in crisis (Torres, 2013). Theories and practical approaches such as those of the influential adult educator Freire $(1970,2004)$ underpin critical pedagogy and this emancipatory model, particularly when it takes place in communities and begins with the learners' experiences, provides personal and local starting points so that concepts such as those in sustainability education and GCE do not become abstractions. Adult and community 
learning promotes and facilitates participation and deliberative democracy, whether it is in a classroom or a community, or on a national or global platform (Brookfield and Holst, 2011). It is, by its very nature, political (Merriam et al., 2012; Torres, 2013), and it connects directly to the discourses of sustainability and global citizenship education.

\section{Ecological global citizenship education: a reframing}

\section{Are we clear about global citizenship?}

The current discourses and daily practice of citizenship and global citizenship exclude many disadvantaged and marginalised groups of people (Lister, 2007). The language used in public discourses, for example, alienates those who are disempowered through poverty and various levels of illiteracy, and who cannot make their voices heard. Therefore, talk of an inclusive global citizenship can seem idealistic. One objection to the use of the word 'citizenship' in a global context is that it has traditionally been linked with a polity, and there is no global polity. However, global citizenship, as understood here, is framed by ethical and political dimensions (Hayden, 2017) and includes the multifaceted perspectives of decolonial, ecological and feminist discourses that recognise that we are all global citizens by the very dint of being human.

The notion of global environmental or ecological citizenship foregrounds responsibilities (Dobson, 2003) and counterbalances the liberal emphasis on rights. Individual and collective responsibilities or duties, within the global frame, are often non-reciprocal and fall primarily on those who occupy unsustainable amounts of ecological space vis-à-vis those in need. Obligations are also extended towards future generations, to ensure a healthy planet for them to inherit (Welsh Government, 2015). The discourse of responsibility is in the domain of ethics, and pertinent arguments include the proposition that the value of a life does not vary according to nationality. Another is the claim by Rorty (1989) that we have a moral obligation to feel a sense of solidarity with all other human beings. He puts aside notions of rational and universal moral deliberations, and focuses on the common, human recognition of suffering as the basis for solidarity. This creates 'a more expansive sense of solidarity than we presently have' (Rorty, 1989: 196) and entails seeing difference (tribe, race and so on) as less important, and thinking of people who are different from ourselves as included in the range of 'us'. It does not mean that we do not value difference, which is important to identity and to a plural vision for citizenship which recognises individuals within unique contexts, with unique experiences and narratives.

\section{An ecological ethos}

Participation, which is a core element of citizenship, implies a world of relationships and interactions. We live and learn in relation. The relationality is akin to an ecological ethos, and it is vital for our well-being and for sustainable development (Helne and Hirvilammi, 2015). There is a web of interdependence, and humans are part of this. We are impacting life on the planet and the life support systems - so much so that the term 'Anthropocene' is used to refer to the geological epoch in which we are living. This is based on the observation that the human-induced instabilities in the Earth system have become so profound that they characterise a new stratigraphical era: 'The knowledge that human activity now rivals geological forces in influencing the trajectory of the Earth System has important implications for both Earth System science and societal decision making' (Steffen et al., 2018: 1). Placing ourselves at the centre has resulted in a destructive trajectory; therefore, an ecological map of the way forward is advocated, one that focuses on the collective and the relational.

Through the realisation that we live in one biosphere, and that we have a shared vulnerability, the need for an ecological global ethos becomes more urgent. This is a relational or systemic orientation, and it embodies the four ecological 'truths' or 'laws': 
- Everything is connected to everything else. There is one ecosphere for all living organisms and what affects one, affects all.

- Everything must go somewhere. There is no 'waste' in nature and there is no 'away' to which things can be thrown.

- Nature knows best. Humankind has fashioned technology to improve upon nature, but such change in a natural system is likely to be detrimental to that system.

- There is no such thing as a free lunch. Exploitation of nature inevitably involves the conversion of resources from useful to useless forms. (Commoner, 1971)

An ecocentric view recognises these as fundamental 'laws'; however, ecocentric is possibly a misnomer because in an ecological ethos there is no centre. Humans, other life forms and the support systems on the planet are interconnected in webs of mutuality. In opposition is an anthropocentric view, which holds that humans are at the centre of the web, and that addressing human needs and wants is the focus even in matters of environmental conservation. Robert Solow (1974: 11), winner of the 1987 Nobel Prize for his work on the economic growth model, stated that 'the world can, in effect, get along without natural resources, so exhaustion is just an event, not a catastrophe.' This extreme anthropocentric view is at the root of the trends outlined by Steffen et al. (2011: 739), who stress the importance of a planetary view: 'As we go further into the Anthropocene, we risk driving the Earth System onto a trajectory toward more hostile states from which we cannot easily return.'

The tensions arising from anthropocentric and ecocentric views are well rehearsed in the field of environmental ethics and law (Attfield, 2018), and in ESD this is discussed by Kopnina (2020), who sees ecocentric education as a critical ecopedagogy that opposes models of growth based on resource exploitation. Ecopedagogy, according to Kopnina (2020: 2) calls for a 'radically different method of addressing the excesses of industrial development and anthropocentrism'. The intrinsic value of nature is part of an ethical ecocentric approach, but the ecological ethos discussed here does not subscribe to an apolitical deep ecology (Naess and Sessions, 1986), which is sometimes associated with an ecocentric view. This reframing advocates for a critical cultural ecoliteracy where world views and relationships to the natural world that challenge Western or Eurocentric assumptions and values are included. This encompasses a decoloniality that endeavours to delink from the theoretical tenets and conceptual instruments of Western thought (Mignolo and Walsh, 2018: 7) and to enable an underpinning ecological ethos that is open, generative and dynamic.

\section{A pedagogical perspective shift}

Pedagogy is not equivalent to education, which includes policy, curriculum and programme design, nor is it equivalent to learning, which can, and does, occur without pedagogy. In pedagogy there is an intentional mediation of knowledge and a creative process focusing on learning transactions. Pedagogy reflects context, and critical pedagogy is grounded in community and in social relations; it also includes the natural, the biological (Burns, 2015; Ellis, 2015). A radical reappraisal of adult education in line with ecopedagogy has been mooted by many authors and 'an ecologically informed adult education should lead to a general rethinking of the core of education and the processes inherent within it' (Bowers, 2017: 53). This aligns with Misiaszek's (2016, 2017) critical ecopedagogy, with Whiting et al.'s (2018a, 2018b) stoic approach to ecopedagogy, and with Burns's (2015) sustainability pedagogy model, which recognises that indigenous wisdom can teach us about creating sustainable and regenerative systems.

Misiaszek (2016, 2020b) cogently discusses environmental global citizenship and ecopedagogy, their antecedents, and the foundational understanding that oppression and social injustice are connected to resource exploitation and environmental destruction. Ecopedagogy chimes with the intersectionality of a transformational adult and community learning approach which moves the problem from the realm 
Figure 1. Comparison of ecopedagogical (left) and modern Stoic cosmopolitan (right) concepts (Source: Whiting et al., 2018a: 7; adapted from Misiaszek, 2016, and Whiting et al. 2018b)
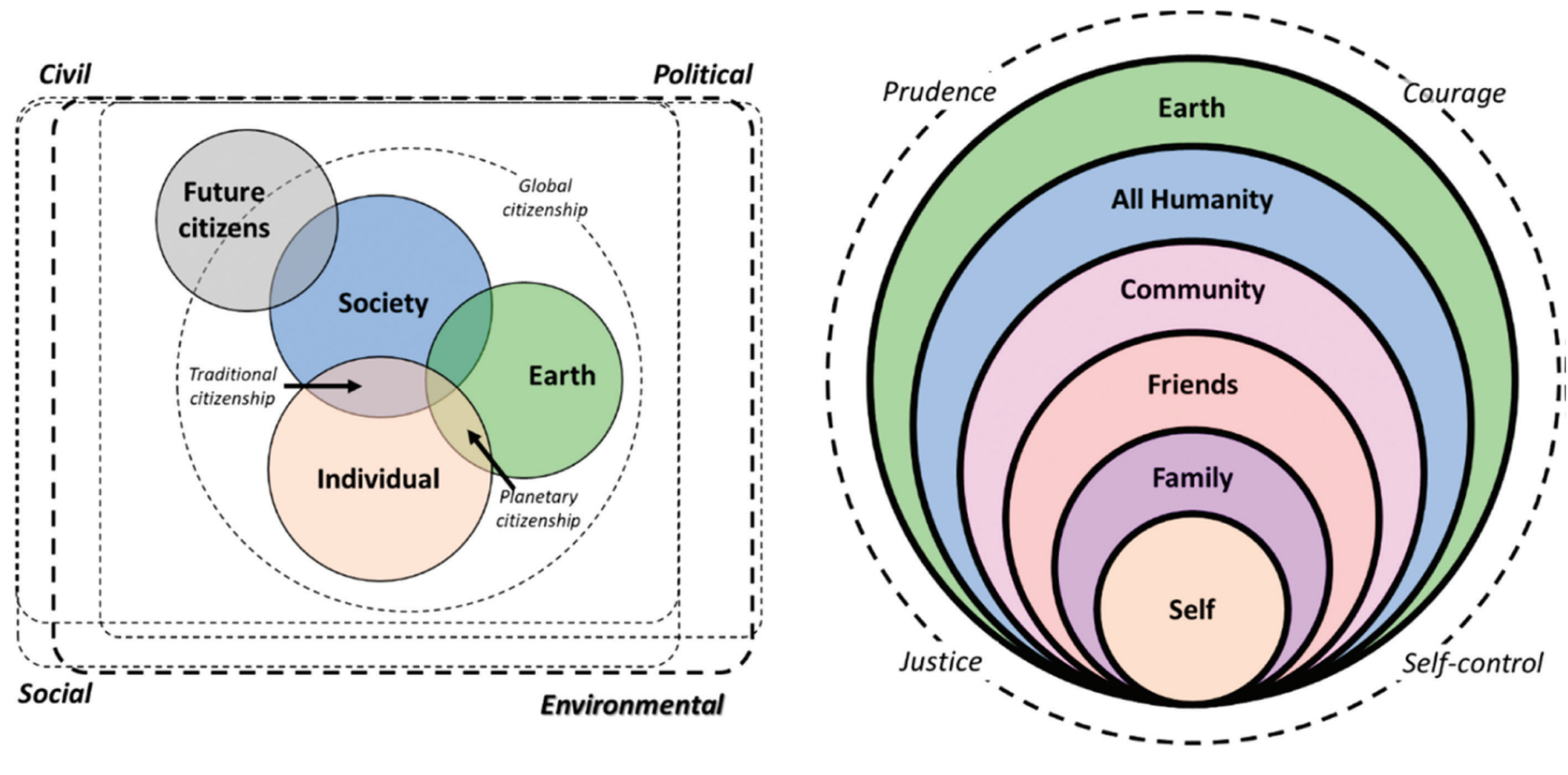

of individual contexts and behaviours to wider, and therefore more useful, understandings of context and dynamic situations. Proponents of ecopedagogy have different nuances and use different conceptual lenses; however, their purpose is in accord (Whiting et al., 2018a), as demonstrated in Figure 1.

Another simple representation that can be used in conjunction with these models is shown in Figure 2.

The use of 'politics', 'ecology' and 'ethics' is a first step in the reframing and integration of sustainability education and GCE:

- ecology is used in place of environment, foregrounding interdependence, relationships and the four laws of ecology

- politics necessitates an explicit examination of the public sphere, power relations and ideology within the context of global citizenship

- ethics involved examining values, and care theory can be included under the rubric of ethics and moral philosophy.

Figure 2. A simple model for ecological global citizenship education (Source: Author, 2021)

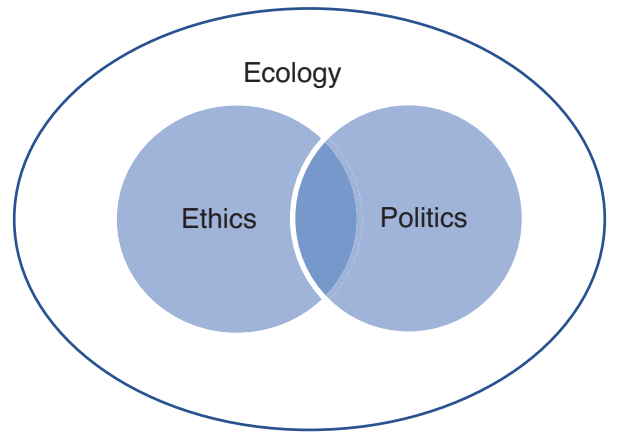


A critical social justice model is at the core of Misiaszek's work on ecopedagogy (2015, 2016, 2017, 2020a, 2020b) and, as an extension to this, I propose the inclusion of care ethics, which centres on the concepts of relationships and interrelationship within the discourses of justice, and offers ethico-political starting points. Another distinguishing feature of the pedagogy proposed here is the recognition of, and engagement with, emotions that facilitate the development of our emotive capacities in learning and acting.

\section{Care theory and ethical starting points}

Care ethics emerged as a moral theory in the second half of the twentieth century. It is not solely concerned with private and domestic relationships; it is a wider and more nuanced, philosophical view of caring, which is relevant to public life, to institutions, social organisation, medicine, international relations and war (Held, 2006: 9). Non-relational care (care that is not justified in terms of interpersonal relations) as a virtue of global citizenship is highlighted by Jackson (2017), and it is bound to political motivation; it moves from caring for to highlight caring about.

In their work on global citizenship and education, Schattle $(2008)$ and Gaudelli $(2003,2016)$ recognise that care ethics offers a more expansive way of thinking about ethical problems than the traditional, Western models that have dominated discourses on justice (Rawls, 2020) and ethics or morality (Roberts, 2013). It places an emphasis on dialogue and negotiation, reflecting both the critical and relational approaches discussed above. It is context driven, situational and particular, while operating in a plural global frame that is not absolutist; it focuses on the lived experience of educators and learners, and it is therefore aligned to the transformational learning model.

Care is invoked in the environmental and political activism we are witnessing in a search for ethical recognition and justice; Tironi and Rodríguez-Giralt (2017), in their work on environmental activism in Chile, examine how care can help enunciate problems and make connections deemed irrelevant by expert apparatuses. New forms of ecological and embodied knowledge can be produced, and the different modes of caring highlight the capacity of care theory for the politicisation of harm and suffering at different levels. 'Care, as it is articulated here, is not a coherent and predefined programme, but a fluid and adaptable ethico-political set of practices and potentialities always concerning specific individuals facing specific problems in specific circumstances' (Tironi and Rodríguez-Giralt, 2017: 89).

In an inclusive global citizenship, all human voices deserve to be heard, and Laugier (2015), in a discussion on ordinary language philosophy, sees this is the starting point of the ethics of care which can provide a framework and guidance for how relations between human beings could develop, locally and internationally. Most people are alienated from ethical discourse, which has traditionally been concerned with abstract norms, even though moral reality includes feelings, emotions and embodied experience (Singer, 2011; Todd, 2010). 'Dominant moral theories tend to interpret moral problems as if they were conflicts between egotistical individual interests on the one hand, and the universal moral principle on the other' (Held, 2006: 10), whereas real life involves a complex web of public and private relationships and interdependencies. Our own flourishing depends, in a vital sense, on the flourishing of others.

Initially, it is worth asking why we should care about the environment, and why we should care about strangers, people who live on the other side of the world, future generations, plants, animals. We probably do care for our family and friends, and, as we mature, we can, by extension, learn to care 'about'. This 'caring about' includes all aspects of life, including the political and public, and care theory fosters inclusion through making public issues more immediate and relevant (Noddings, 2013). It is an aspect of justice that seeks interconnections and focuses on relationships, whereas justice traditionally seeks a fair solution between competing interests. There is a need for both orientations, and the dominant social justice model in adult education and in ecopedagogy might be balanced with care discourses.

Held (2010), Engster and Hamington (2015) and Koggel and Orme (2019) outline the role of care ethics in addressing current social and political issues. 'The ethics of care provides a way of thinking about and evaluating both the more immediate and the more distant human relations with which to develop 
morally acceptable societies' (Held, 2006: 43). Okano (2016) explicitly notes the potential of the ethics of care as a political philosophy, providing a new approach as it focuses on relationships and a collective, connective model of justice as an alternative to neoliberalism in the context of contemporary global politics. Care theory represents an important alternative in public discourses and to politics-as-usual; it can reorient our understanding of ethics and politics, and guide us in addressing contemporary problems (Engster and Hamington, 2015). The inclusion of care theory expands pedagogical possibilities, and offers new theoretical, political and empirical agendas where we can locate ethical discourses globally, beyond Western agendas (Raghuram, 2016, 2019).

\section{Uncomfortable learning and emotions}

In a climate where we are witnessing political polarisation, media control, censorship and civic apathy, discussing so-called controversial issues becomes more important (McAvoy and Hess, 2013). These conversations are complex, and often emotive, and it is critical that we include them, no matter how uncomfortable. Facilitating learning on the topics that emerge in an ecological global citizenship education requires skill and sensitivity on the part of the teacher as we examine our values and motives while supporting a dialogic learning (Brookfield and Preskill, 2012).

Dialogue is recognised as one of the main methods in critical pedagogy (Brookfield, 2011; Brookfield and Preskill, 2012; Freire, 1970, 2004; Todd, 2015); it is the method at the intersection of individual and collective learning (Johnson and Morris, 2010). Dialogue can facilitate engagement with uncomfortable issues, develop critical consciousness and holistic understandings; 'For the Brazilian educator Paulo Freire, dialogue is a hinge concept, one that potentially connects scientific with humanistic knowledge, theory with practice, and human nature with human behaviour' (Cissna and Anderson, 2012: 173). In transformative learning, dialogue is the dialectic where learners at times teach, and teachers are open to learning from students. Speaking, listening and sharing thoughts and feelings with one another as a dialogue with intent is part of the process of transformative learning; it is a praxis which is both profound and practical (Cissna and Anderson, 2012).

Becoming engaged in classroom dialogue enables us to face our humanity, and it can have an important role in shaping an agenda for realigning the purpose and pedagogy of adult education towards ecological global citizenship. Dialogue has two broad purposes: it is a method where content is learned and understood through interaction and communication, and it also develops useful life skills, such as the ability to listen, to articulate thoughts and feelings, to develop emotional intelligence, to respond appropriately to others, and to formulate arguments and express ourselves clearly. There is certainly a place for technical dialogue, but here we are considering dialogue in a deeper sense, where it involves the whole person: reason and emotions, rationality and feelings. The ethics of care is hospitable to the methods of discourse ethics that empowers participants to express themselves, it embodies intersubjective learning where understandings are reached, and it helps people to express different perspectives and realise their common interests. Institutional structures and constraints do not always lend themselves to classroom dialogue; however, dialogue has the advantage that it can be employed in a range of classroom contexts without the need for a great many resources; it is an accessible practice.

Bohm (2013) strongly advocates dialogue as the means to engage with emotions such as anger, and to examine human thought; he feels that this endeavour is vital, considering global suffering, conflict and environmental destruction. As global, local and personal concerns are discussed in a classroom, learning can become uncomfortable as contentious and emotive issues arise (Hess, 2009; Jenkins, 2018). Facing painful realities and using them in learning is frequently uncomfortable. This discomfort is referred to by different names, including 'disorienting dilemma' (Mezirow, 2000), 'disjuncture' (Jarvis, 2006), 'dissonance' (Todd, 2010), a pedagogy of 'dissensus' (Andreotti, 2011), and 'blessed unrest' (Selby and Kagawa, 2011). This disharmony or 'disjuncture' is what forces us to reflect and ask questions so that we can restore equilibrium in ourselves, in our lives and in the world. 
These uncomfortable learning states are usually emotional, and Hoggan et al. (2017: 55) use the term 'edge emotions'. They can motivate us to respond intelligently and humanely to troubling questions. Examining political anger, White (2012) discusses how we can use this emotion, arguing that we, in a democracy, cannot dispense with political anger, and that it has a role in enabling us to protect what we value. A pedagogy that engages with emotions can provide learners with 'a repertoire of ways of expressing democratic anger' (White, 2012: 1), so that they do not become apathetic or fearful. Jackson (2017), who discusses non-relational care as a virtue of global citizenship, cautions against emotions without the foundation of skills for systemic action. Therefore, the model proposed here connects the emotional with a rational, critical ecological pedagogy. Reason and emotions can work together as we navigate ethical issues and explore values and beliefs in sustainability education and GCE (Saunders, 2016), and emotions play a key role in decision-making and in knowledge creation (Candiotto, 2019). Attending to emotions and feelings in contexts, interactions and relationships enables the development of higherorder skills, and recent work in neuroscience demonstrates the crucial role of emotional intelligence and how emotions help us create meaning (Immordino-Yang, 2015).

Engster (2015) demonstrates that we have an innate disposition for caring, and challenges a traditional Western conception of people as predominantly independent and self-interested. If we ignore this biological, natural disposition to caring, we distort our understanding of human nature and the underpinnings of morality and society. Ignoring the vital role that emotions play in our reasoning, decision-making and learning could be dangerous. Emotions such as guilt, fear, despair and anger, if they are not understood and dealt with, can be damaging; learners can disengage or behave in ineffective, destructive or even violent ways.

Andreotti et al. (2010) state that the affective dimensions help learners to challenge norms, and that engagement with emotions might help us engage more fully with the complexities of human learning and living (Andreotti et al., 2010: 17). Taylor (in Andreotti et al., 2010; 13) states that she is interested in the ways that global justice education might attend to the affective dynamics of learning in a pedagogy that includes self-knowledge; she argues that these concerns are 'central to the experience of global justice learning'. In Pashby et al.'s (2020) meta review of typologies of global citizenship education, the questions asked in conclusion to the analysis include those about the affective domain and care. Pashby et al. (2020: 159-60) ask what approaches to GCE can support learners to make visible and explore different ontologies:

What can engender a stream of connections and a sense of care and commitment towards everything that overrides self-interest and insecurities and is not dependent on convictions, knowledge, identity or understanding? What would it look and feel like if our responsibility to all living beings on the planet was not a willed choice, but rather something 'before will'?

The deep wounds of colonialism are felt all over the world. Indigenous and aboriginal people have suffered genocides and continue to suffer from ongoing injustices. The desecration of the land and of life invokes emotional responses that can facilitate learning about systemic issues, humanity and what matters most. Colonial legacies affect us all and shape the ecological, affective, cognitive, relational and economic dimensions of our existence (Stein et al., 2019). This necessitates relational learning that is not oriented by rational, utility-focused choices, but rooted in 'humility, compassion, generosity, and affirmation of collective responsibilities (before will) as part of a wider social and ecological metabolism' (Stein et al., 2019: 29). This orientation opens possibilities for reimagining ethical starting points in learning:

A decolonial approach to ethics identifies the need for transitional practices, pedagogies, and engagements through which those who were socialized within a liberal global imaginary can work through not only the cognitive and material but also the affective and relational challenges of change. (Stein et al., 2019: 28) 


\section{Conclusion}

The integration of sustainability education and global citizenship education is an ongoing project, and this article has suggested a pedagogy that foregrounds ethical and political issues within an ecological ethos. A conceptual framework that can include plural perspectives and ontologies while being rooted in learning theory is proposed.

The model is called an ecological global citizenship, and it is informed by the discourses of transformative adult education which include ideology critique, intersubjectivity and relational learning, using the learners' experiences as starting points and having an emancipatory, social justice orientation. Ecopedagogy emphasises this critical social justice orientation, and the model proposed here expands this to include care theory, which approaches justice from a relational perspective. It seeks interconnections, it is dialogic in nature, context driven and focuses on lived experience. In addition, the model proposed here explicitly emphasises the affective domain of learning, where the range of emotional responses are attended to. Learning and behaviour can be more effective and rational when we attend to emotions, and a pedagogy that includes developing emotional intelligence (Goleman, 2020; Immordino-Yang, 2015) can address the anxiety, worry, apathy, helplessness, hopelessness or cynicism one might encounter with learners. Systemic problem solving requires a range of cognitive and affective skills competencies.

Care theory is a lens through which to engage with the ethico-political dimensions of ecological global citizenship. Care theory lends itself to a pedagogy where emotions are valued as part of the learning process; it provides ethical starting points for the uncomfortable learning associated with confronting the issues in sustainability education and GCE, and it centres on relationships and interdependencies in accord with an ecological ethos. Public discourses become sincere and more legitimate when caring and interconnections are articulated, and this provides a foundation for participation and inclusion, as abstract norms are substituted by lived experience.

A dialogic method that embodies critical and relational orientations, where we listen and seek to understand each other, is at the centre of this pedagogical model; it is the intersection between the

Figure 3. A model for an ecological global citizenship education (Source: Author, 2021, based on a model proposed by Johnson and Morris, 2010: 80)

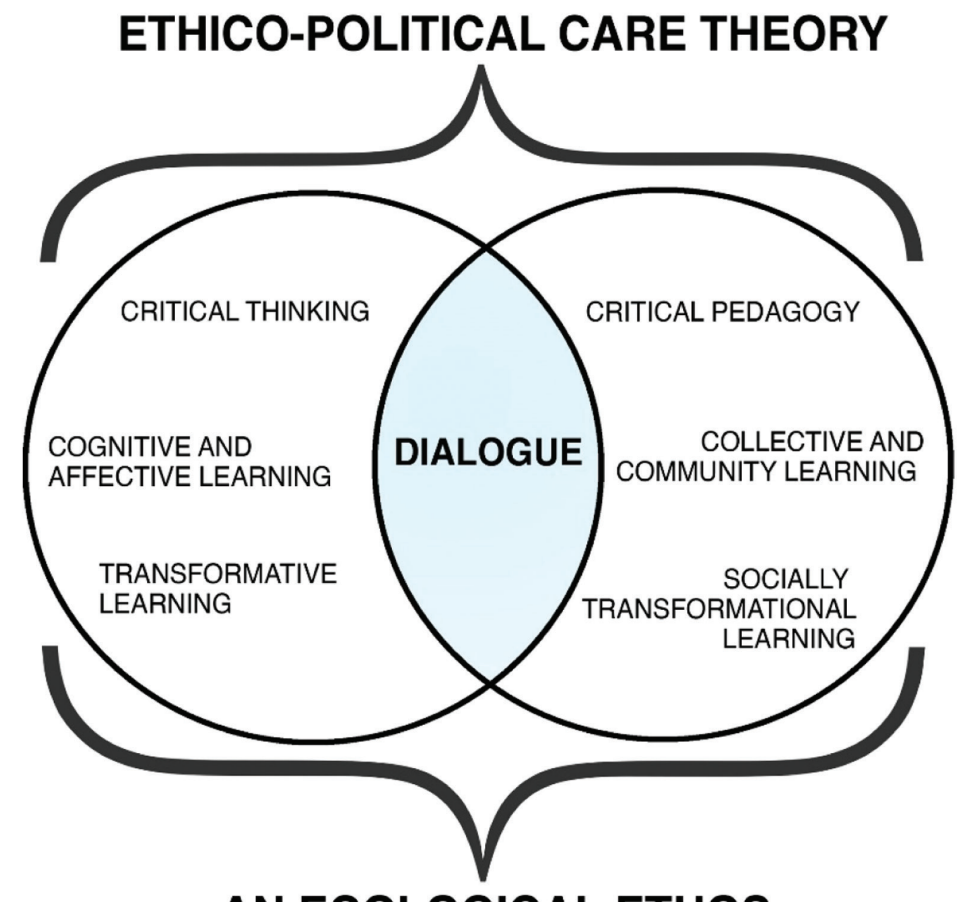

AN ECOLOGICAL ETHOS 
individual and the collective. It can support educators and learners to address complex issues and, in the process, develop a repertoire of skills that enable us to respond humanely to each other, and to situations and subjects, be they immediate, personal, local, national or global. Educators who facilitate dialogue and discussion explore and challenge their own and learners' beliefs and values, and it is vital that they are supported in this, so that a bland neutrality or cultural relativism does not prevail, and that learning outcomes are understood and agreed with adult learners (Jenkins, 2018: 254).

Embodied in this model is the notion of conscientisation (Freire, 1970), where we develop critical consciousness through experience, reflection and dialogue; we become engaged in ethico-political discourses that recognise interdependence within a shared biosphere; we take responsibility as private and public individuals, and we learn and act collectively, compassionately and in solidarity as global citizens (see Figure 3).

This fluid model is a contribution to the urgent debates regarding an education that recognises the unity of life on earth, and the systems that support it.

\section{Declarations and conflicts of interest}

\section{Conflicts of interest statement}

The author declares no conflict of interest with this work. All efforts to sufficiently blind the author during peer review of this article have been made.

\section{Consent for publication statement}

The author declares that research participants' informed consent to publication of findings - including photos, videos and any personal or identifiable information - was secured prior to publication.

\section{References}

Agyeman, J. (2005) Sustainable Communities and the Challenge of Environmental Justice. New York: New York University Press.

Andreotti, V. (2010) 'Postcolonial and post-critical "global citizenship education"'. In G. Elliott, C. Fourali and S. Issler (eds), Education and Social Change: Connecting local and global perspectives. London: Bloomsbury, 238-50.

Andreotti, V. (2011) '(Towards) decoloniality and diversality in global citizenship education'. Globalisation, Societies and Education, 9 (3-4), 381-97. https://doi.org/10.1080/14767724.2011.605323.

Andreotti, V. and Souza, L.M.T. (eds) (2012) Postcolonial Perspectives on Global Citizenship Education. London: Routledge.

Andreotti, V., Jefferess, D., Pashby, K., Rowe, C., Tarc, P. and Taylor, L. (2010) 'Difference and conflict in global citizenship in higher education in Canada'. International Journal of Development Education and Global Learning, 2 (3), 5-24. https://doi.org/10.18546/IJDEGL.02.3.02.

Attfield, R. (2018) Environmental Ethics: A very short introduction. Oxford: Oxford University Press.

Bamber, P., Bullivant, A., Glover, A., King, B. and McCann, G. (2016) 'A comparative review of policy and practice for education for sustainable development/education for global citizenship (ESD/GC) in teacher education across the four nations of the UK'. Management in Education, 30 (3), 112-20. https://doi.org/10.1177\%2F0892020616653179.

Bennell, S. (2011) 'The Development of ESDGC Initiatives in Initial Teacher Training Education and Training in Wales'. Bangor: Bangor University.

Bohm, D. (2013) On Dialogue. London: Routledge.

Bourn, D. (2014) The Theory and Practice of Development Education: A pedagogy for global social justice. London: Routledge.

Bowers, C.A. (2001) Educating for Eco-Justice and Community. Athens: University of Georgia Press.

Bowers, C.A. (2002) 'Toward an eco-justice pedagogy'. Environmental Education Research, 8 (1), 21-34. https://doi.org/10.1080/13504620120109628.

Bowers, C.A. (2005) 'Is transformative learning the Trojan Horse of Western globalization?'. Journal of Transformative Education, 3 (2), 116-25. https://doi.org/10.1177\%2F1541344604273622. 
Bowers, C.A. (2017) 'An ecojustice approach to educational reform in adult education'. New Directions for Adult and Continuing Education, (153), 53-64. https://doi.org/10.1002/ace.20221.

Brookfield, S.D. (2011) Teaching for Critical Thinking: Tools and techniques to help students question their assumptions. San Francisco: John Wiley and Sons.

Brookfield, S.D. and Holst, J.D. (2011) Radicalizing Learning: Adult education for a just world. San Francisco: Jossey-Bass

Brookfield, S.D. and Preskill, S. (2012) Discussion as a Way of Teaching: Tools and techniques for democratic classrooms. 3rd ed. San Francisco: John Wiley and Sons.

Burns, H.L. (2015) 'Transformative sustainability pedagogy: Learning from ecological systems and indigenous wisdom'. Journal of Transformative Education, 13 (3), 259-76. https://doi.org/10.1177\%2F1541344615584683.

Candiotto, L. (ed.) (2019) The Value of Emotions for Knowledge. Springer.

Cissna, K.N. and Anderson, R. (2012) Moments of Meeting: Buber, Rogers, and the potential for public dialogue. New York: SUNY Press.

Commoner, B. (1971) The Closing Circle: Nature, man, and technology. New York: Bantam Books.

Dobson, A. (2003) Citizenship and the Environment. Oxford: Open University Press.

Dobson, A. (2005) 'Globalisation, cosmopolitanism and the environment'. International Relations, 19 (3), $259-73$. https://doi.org/10.1177\%2F0047117805055406.

Dobson, A. (2007) 'Environmental citizenship: Towards sustainable development'. Sustainable Development, 15 (5), 276-85. https://doi.org/10.1002/sd.344.

Ellis, M. (2015) The Critical Global Educator: Global citizenship education as sustainable development. London: Routledge.

Engster, D. (2015) 'Care in the state of nature'. In D. Engster and M. Hamington (eds), Care Ethics and Political Theory. Oxford: Oxford University Press, 226-51.

Engster, D. and Hamington, M. (eds) (2015) Care Ethics and Political Theory. Oxford: Oxford University Press.

Freire, P. (1970) Pedagogy of the Oppressed. Trans. M.B. Ramos. New York: Continuum.

Freire, P. (2004) Pedagogy of Indignation. Boulder: Paradigm.

Gaudelli, W. (2003) World Class: Teaching and learning in global times. Mahwah, NJ: Lawrence Erlbaum Associates.

Gaudelli, W. (2016) Global Citizenship Education: Everyday transcendence. New York: Routledge.

Goleman, G. (2020) Emotional Intelligence and Why It Matters More Than IQ. London: Bloomsbury.

Hayden, P. (2017) Cosmopolitan Global Politics. 2nd ed. Aldershot: Ashgate.

Heater, D. (2013) What is Citizenship? 5th ed. New Jersey: John Wiley \& Sons.

Held, V. (2006) The Ethics of Care: Personal, political and global. New York: Oxford University Press.

Held, V. (2010) 'Can the ethics of care handle violence?'. Ethics and Social Welfare, 4 (2), 115-29. https://doi.org/10.1080/1 7496535.2010 .484256

Helne, T. and Hirvilammi, T. (2015) 'Wellbeing and sustainability: A relational approach'. Sustainable Development, 23 (3), 167-75. https://doi.org/10.1002/sd.1581.

Hess, D.E. (2009) Controversy in the Classroom: The democratic power of discussion. New York: Routledge.

Hoggan, C., Mälkki, K. and Finnegan, F. (2017) 'Developing the theory of perspective transformation: Continuity, intersubjectivity, and emancipatory praxis'. Adult Education Quarterly, 67 (1), 48-64. https://doi.org/10.1177\% 2F0741713616674076.

Huckle, J. (2012) 'Towards greater realism in learning for sustainability'. In E.J. Wals and P.B. Corcoran (eds), Learning for Sustainability. Wageningen: Wageningen Academic, 35-48.

Huckle, J. (2014) 'Education for sustainable citizenship: An emerging focus for education for sustainability'. In J. Huckle and S. Sterling (eds), Education for Sustainability. 2nd ed. London: Routledge, 228-43.

Huckle, J. and Wals, A.E. (2015) 'The UN decade of education for sustainable development: Business as usual in the end'. Environmental Education Research, 21 (3), 491-505. https://doi.org/10.1080/13504622.2015.1011084.

Immordino-Yang, M.H. (2015) Emotions, Learning, and the Brain: Exploring the Educational Implications of Affective Neuroscience. New York: WW Norton \& Company.

Jackson, L. (2017) 'Altruism, non-relational care, and global citizenship education'. Philosophy of Education Archive, $409-17$. Accessed 15 September 2021. https://educationjournal.web.illinois.edu/archive/index.php/pes/article/view/4900.pdf.

Jarvis, P. (2006) Human Learning. London: Routledge.

Jenkins, A. (2018) 'Education for Sustainable Development and Global Citizenship in Adult and Community Learning in Wales, from Policy to Pedagogy'. PhD thesis, Swansea University.

Johnson, L. and Morris, P. (2010) 'Towards a framework for critical citizenship education'. The Curriculum Journal, 21 (1), 77-96. https://doi.org/10.1080/09585170903560444

Koggel, C.M. and Orme, J. (eds) (2019) Care Ethics: New theories and applications. London: Routledge.

Kopnina, H. (2020) 'Ecocentric education: Introduction to a special collection of essays'. Education Sciences, 10 (9), 217. https://doi.org/10.3390/educsci10090217. 
Laugier, S. (2015) 'The ethics of care as a politics of the ordinary'. New Literary History, 46 (2), 217-40. https://doi.org/10.1353/NLH.2015.0016.

Lister, R. (2007) 'Inclusive citizenship: Realising the potential'. Citizenship Studies, 11 (1), 49-61. https://doi.org/10.1080/ 13621020601099856.

Lysaker, J.T. and Furuness, S. (2011) 'Space for transformation: Relational, dialogic pedagogy'. Journal of Transformative Education, 9 (3), 183-97. https://doi.org/10.1177\%2F1541344612439939.

McAvoy, P. and Hess, D. (2013) 'Classroom deliberation in an era of political polarization'. Curriculum Inquiry, 43 (1), 14-47. https://doi.org/10.1111/curi.12000.

Merriam, S.B., Caffarella, R.S. and Baumgartner, L.M. (2012) Learning in Adulthood: a comprehensive guide. 4th ed. Hoboken, NJ: John Wiley and Sons.

Mezirow, J. (1981) 'A critical theory of adult learning and education'. Adult Education (Adult Education Association of the USA, Washington), 32 (1), 3-24. https://doi.org/10.1177\%2F074171368103200101.

Mezirow, J. (2000) 'Learning to think like an adult: Core concepts of transformative theory'. In J. Mezirow (ed.), Learning as Transformation: Critical perspectives on a theory in progress. San Francisco: Jossey-Bass, 3-33.

Mignolo, W.D. and Walsh, C.E. (2018) On Decoloniality. Durham, NC: Duke University Press.

Misiaszek, G.W. (2015) 'Ecopedagogy and citizenship in the age of globalisation: Connections between environmental and global citizenship education to save the planet'. European Journal of Education, 50 (3), $280-92$. https://doi.org/10.1111/ejed.12138.

Misiaszek, G.W. (2016) 'Ecopedagogy as an element of citizenship education: The dialectic of global/local spheres of citizenship and critical environmental pedagogies'. International Review of Education, 62 (5), 587-607. https://doi.org/10.1007/s11159-016-9587-0.

Misiaszek, G.W. (2017) Educating the Global Environmental Citizen: Understanding ecopedagogy in local and global contexts. London: Routledge.

Misiaszek, G.W. (2020a) 'Countering post-truths through ecopedagogical literacies: Teaching to critically read "development" and "sustainable development"'. Educational Philosophy and Theory, 52 (7), 747-58. https://doi.org/10.1080/00131857.2019.1680362.

Misiaszek, G.W. (2020b) Ecopedagogy: critical environmental teaching for planetary justice and global sustainable development. London: Bloomsbury.

Naess, A. and Sessions, G. (1986) 'The basic principles of deep ecology'. The Trumpeter, 3 (4), 14. Accessed 15 September 2021. http://trumpeter.athabascau.ca/index.php/trumpet/article/view/579/1241.

Noddings, N. (2013) Caring: A relational approach to ethics and moral education. 2nd ed. Berkeley: University of California Press.

Norcliffe, D. and Bennell, S. (2010) 'Analysis of views on the Education for Sustainable Development and Global Citizenship Policy in Wales'. International Journal of Development Education and Global Learning, 3 (1), 39-58. https://doi.org/10.18546/IJDEGL.03.1.04.

Okano, Y. (2016) 'Why has the ethics of care become an issue of global concern?'. International Journal of Japanese Sociology, 25 (1), 85-99. https://doi.org/10.1111/ijjs.12048.

Oxley, L. and Morris, P. (2013) 'Global citizenship: A typology for distinguishing its multiple conceptions'. British Journal of Educational Studies, 61 (3), 301-25. https://doi.org/10.1080/00071005.2013.798393.

Pashby, K., da Costa, M., Stein, S. and Andreotti, V. (2020) 'A meta-review of typologies of global citizenship education'. Comparative Education, 56 (2), 144-64. https://doi.org/10.1080/03050068.2020.1723352.

Raghuram, P. (2016) 'Locating care ethics beyond the Global North'. ACME: An International Journal for Critical Geographies, 15 (3), 511-33. Accessed 15 September 2021. https://acme-journal.org/index.php/acme/article/ view/1353.

Raghuram, P. (2019) 'Race and feminist care ethics: Intersectionality as method'. Gender, Place \& Culture, 26 (5), $613-37$. https://doi.org/10.1080/0966369X.2019.1567471.

Rawls, J. (2020) A Theory of Justice. Cambridge, MA: Harvard University Press.

Roberts, R.C. (2013) Emotions in the Moral Life. Cambridge: Cambridge University Press.

Rorty, R. (1989) Contingency, Irony and Solidarity. Cambridge: Cambridge University Press.

Rorty, R. (1998) Truth and Progress: Philosophical papers (Vol. 3). Cambridge: Cambridge University Press.

Saunders, L.F. (2016) 'Reason and emotion, not reason or emotion in moral judgment'. Philosophical Explorations, 19 (3), 252-67. https://doi.org/10.1080/13869795.2016.1212395.

Schattle, H. (2008) The Practices of Global Citizenship. Lanham, MD: Rowman \& Littlefield.

Schattle, H. (2012) Globalization and Citizenship. Lanham, MD: Rowman \& Littlefield.

Selby, D. and Kagawa, F. (2011) 'Unleashing blessed unrest as the heating happens'. Green Teacher, (94), 3-15. Accessed 15 September 2021. https://greenteacher.com/article\%20files/Unleashing\%20Blessed\%20Unrest\%20As\%20the\%20 Heating\%20Happens.pdf.

Singer, P. (2011) Practical Ethics. 3rd ed. Cambridge: Cambridge University Press. 
Solow, R.M. (1974) 'The economics of resources or the resources of economics'. In C. Gopalakrishnan (ed.), Classic Papers in Natural Resource Economics. London: Palgrave Macmillan, 257-76.

Steffen, W., Persson, Å., Deutsch, L., Zalasiewicz, J., Williams, M., Richardson, K., Crumley, C., Crutzen, P., Folke, C., Gordon, L., Molina, M., Ramanathan, V., Rockström, J., Scheffer, M., Schellnhuber, H.J. and Svedin, U. (2011) 'The Anthropocene: From global change to planetary stewardship'. Ambio, 40 (7), 739-61. https://doi.org/10.1007/s13280011-0185-x.

Steffen, W., Richardson, K., Rockström, J., Cornell, S.E., Fetzer, I., Bennett, E.M., Biggs, R., Carpenter, S.R., de Vries, W., de Wit, C.A., Folke, C., Gerten, D., Heinke, J., Mace, G.M., Persson, L.M., Ramanathan, V., Reyers, B. and Sörlin, S. (2015) 'Planetary boundaries: Guiding human development on a changing planet'. Science, 347 (6223), 1259855. https://doi.org/10.1126/science.1259855.

Steffen, W., Rockström, J., Richardson, K., Lenton, T.M., Folke, C., Liverman, D., Summerhayes, C.P., Barnosky, A.D., Cornell, S.E., Crucifix, M., Donges, J.F., Fetzer, I., Lade, S.J., Scheffer, M., Winkelmann, R. and Schellnhuber, H.J. (2018) 'Trajectories of the Earth System in the Anthropocene'. Proceedings of the National Academy of Sciences, 115 (33), 8252-9. https://doi.org/10.1073/pnas.1810141115.

Stein, S., Andreotti, V. and Suša, R. (2019) 'Pluralizing frameworks for global ethics in the internationalization of higher education in Canada'. Canadian Journal of Higher Education/Revue canadienne d'enseignement supérieur, 49 (1), 22-46. https://doi.org/10.7202/1060822ar.

Sund, L. and Pashby, K. (2020) 'Delinking global issues in northern Europe classrooms'. The Journal of Environmental Education, 51 (2), 156-70. https://doi.org/10.1080/00958964.2020.1726264.

Taylor, E.W. and Snyder, M.J. (2012) 'A critical review of research on transformative learning theory, 2006-2010'. In E.W Taylor and P. Cranton (eds), The Handbook of Transformative Learning: Theory, research, and practice. San Francisco: John Wiley \& Sons, 37-55.

Tironi, M. and Rodríguez-Giralt, I. (2017) 'Healing, knowing, enduring: Care and politics in damaged worlds'. The Sociological Review, 65 (2 suppl), 89-109. https://doi.org/10.1177\%2F0081176917712874.

Todd, S. (2010) 'Living in a dissonant world: Toward an agonistic cosmopolitics for education'. Studies in Philosophy and Education, 29 (2), 213-28. https://doi.org/10.1007/s11217-009-9171-1.

Todd, S. (2015) Toward an Imperfect Education: Facing humanity, rethinking cosmopolitanism. 2nd ed. London: Routledge.

Torres, C.A. (2013) Political Sociology of Adult Education. Rotterdam: Sense.

UNESCO (United Nations Educational, Scientific and Cultural Organization) (2010) Education for Sustainable Development in the UK in 2010. London: UK National Commission for UNESCO. Accessed 20 September 2021. https://www.eauc.org.uk/from_the_chair_of_uk_national_commission_for_un.

UNESCO (United Nations Educational, Scientific and Cultural Organization) (2013) Education for Sustainable Development (ESD) in the UK - Current status, best practice and opportunities for the future. London: UK National Commission for UNESCO. Accessed 20 September 2021. https://www.eauc.org.uk/file_uploads/uknc_esd_policy_ brief.pdf.

UNESCO (United Nations Educational, Scientific and Cultural Organization) (2014) Shaping the Future we Want: UN Decade Of Education for Sustainable Development (2005-2014) Final report. Paris: UNESCO.

United Nations (2019) 'Global Environment Outlook'. Accessed 15 September 2021. https://www.unenvironment.org/ global-environment-outlook.

Warburton, D. (ed.) (2013) Community and Sustainable Development: Participation in the future. 2nd ed. London: Routledge.

Welsh Government (2008) Education for Sustainable Development and Global Citizenship: A strategy for action. Cardiff: Welsh Government.

Welsh Government (2015) The Well-Being of Future Generations (Wales) Act 2015: The essentials. Accessed 20 September 2021. https://www.futuregenerations.wales/about-us/future-generations-act/.

White, P. (2012) 'Making political anger possible: A task for civic education'. Journal of Philosophy of Education, 46 (1), 1-13. https://doi.org/10.1111/j.1467-9752.2012.00837.x.

Whiting, K., Konstantakos, L., Carrasco, A. and Carmona, L.G. (2018a) 'Sustainable development, wellbeing and material consumption: A stoic perspective'. Sustainability, 10 (2), 474. https://doi.org/10.3390/su10020474.

Whiting, K., Konstantakos, L., Misiaszek, G., Simpson, E. and Carmona, L.G. (2018b) 'Education for the sustainable global citizen: What can we learn from stoic philosophy and Freirean environmental pedagogies?'. Education Sciences, 8 (4), 204. https://doi.org/10.3390/educsci8040204. 